

P-ISSN: 2349-8528

E-ISSN: 2321-4902

www.chemijournal.com

IJCS 2020; 8(4): 1272-1275

(C) 2020 IJCS

Received: 19-05-2020

Accepted: 21-06-2020

NG Patel

Department of Horticulture,

State Government of Gujarat,

Gandhinagar, Gujarat, India

DD Parekh

Department of Horticulture, Anand Agriculture University, Anand, Gujarat, India

RP Vasara

Department of Horticulture, State Government of Gujarat, Ahmedabad, Gujarat, India

Corresponding Author:

NG Patel

Department of Horticulture,

State Government of Gujarat,

Gandhinagar, Gujarat, India

\section{Influence of post-harvest application of ethrel and paper wrapping on physical parameter and ripening of papaya (Carica papaya $L$.) Cv. Madhu Bindu}

\author{
NG Patel, DD Parekh and RP Vasara
}

DOI: https://doi.org/ 10.22271/chemi.2020.v8.i4k.9777

\begin{abstract}
Papaya (Carica papaya L.) is an important and a very popular fruit crop of the tropical and subtropical areas in the world. The experiment was conducted to study the "influence of post-harvest application of ethrel and paper wrapping on papaya (Carica papaya L.) cv. Madhu Bindu” during kharif, 2017 at Department of Horticulture, B. A. College of Agriculture, Anand Agricultural University, Anand(Gujarat). The experiment was framed in completely Randomized Design with factorial concept replicated thrice with ten treatment combination. The treatment were comprised of five different concentration of ethrel $(0 \mathrm{mg} / \mathrm{l}, 500 \mathrm{mg} / \mathrm{l}, 750 \mathrm{mg} / \mathrm{l}, 1000 \mathrm{mg} / \mathrm{l}$ and $1250 \mathrm{mg} / \mathrm{l})$ along with paper wrapping (with paper wrapping and without paper wrapping). Fruit dipped in ethrel @ $1250 \mathrm{mg} / \mathrm{l}$ shows early ripening. Significantly minimum PLW $(\%)$ and spoilage $(\%)$ while, maximum firmness and shelf life were observed with no-ethrel treatment $(0 \mathrm{mg} / \mathrm{l})$. In case of paper wrapping significantly maximum firmness, minimum PLW and early ripening was observed with paper wrapping while, significantly minimum spoilage and long shelf life was observed in non-wrapped fruit.
\end{abstract}

Keywords: Post-harvest treatment, ethrel, physical parameter, papaya, dipping, ripening

\section{Introduction}

Papaya (Carica papaya L.) belonging to the family caricaceae, is one of the most important fruits cultivated throughout the tropical and subtropical regions of the world. Presently, papaya cultivation is spread over tropical and sub-tropical part of the world covering $32^{\circ} \mathrm{N}$ and $32^{\circ} \mathrm{S}$ on the globe. Top twenty papaya cultivating countries are distributed in Asia (India, Bangladesh, Thailand, Indonesia, Philippines, Malaysia and China), Africa (Nigeria, Ethiopia, Congo, Kenya, Ivory Coast and Mozambique), Latin and Central America (Brazil, Mexico, Venezuela, Colombia and Cuba). Some developed countries like USA (Hawaii), Australia, South Africa and Taiwan also cultivate papaya. India is supposed to be the largest producer of papaya in the world. Papaya occupies $1.8 \%$ of total fruit crop area and $6.3 \%$ of total fruit production in India. It occupies a cultivated area of 133.4 (000 ha) with an annual production of 5699.00 (000 MT) and productivity of 42.3 (MT/ha). Papaya is an abundant source of carotene (2020 I.U./100g), precursor of vitamin A. Papaya fruits are used for the treatment of piles, dyspepsia of spleen and liver, digestive disorders, diphtheria and skin blemishes.

Ethrel is an ethylene-releasing chemical, which can be used to improve fruit color development and stimulates ripening process of the fruit. Fruit ripening is a genetically programmed stage of development overlapping with senescence (Watada et al., 1984) ${ }^{[25]}$. Aqueous solution of ethrel is stable below pH 3.5. Above $\mathrm{pH} \mathrm{3.5,} \mathrm{the} \mathrm{hydrolysis} \mathrm{of} \mathrm{ethrel}$ begins with the release of free ethylene along with chloride and phosphate ions. On dipping the mature fruits in ethrel, it enters into the fruit cells, releases ethylene and hastens the ripening process. Ethrel has been found very effective growth regulator in ripening and improving fruit quality in many climacteric fruits.

Different wrapping materials are being used by fruit growers to prolong the storage life. Skin evaporation (transpiration) and to some extent respiration cause a loss of water from fruit and this loss in weight can be effectively cut down by the use of various packaging materials like polythene, tissue paper, newspaper, paddy straw and shrink film. 
Keeping these in view, the present experiment is undertaken to see the "Influence of post-harvest application of ethrel and paper wrapping on physical parameter and ripening of papaya (Carica papaya L.) cv. Madhu Bindu" fruit kept at ambient temperatures.

\section{Materials and methods}

The present investigation entitled "Influence of post-harvest application of ethrel and paper wrapping on papaya (Carica papaya L.) cv. Madhu Bindu" was carried out at Laboratory of the Department of Horticulture, B. A. College of Agriculture, Anand Agricultural University, Anand (Gujarat) during the year 2017. The fruits of papaya cv. Madhu Bindu which were physiologically mature and have attained the full size, light green with tinge of yellow at apical end were used for the study. The fruits were selected on the basis of uniformity, maturity, size and shape. The experiment was laid out in Completely Randomized Design (CRD) with five treatments and three replications.

The fruits were washed with clean water and dipped for five minutes in the following concentrations of Ethrel solution. i.e. control ( $\left.\mathrm{E}_{0}\right), 500 \mathrm{ppm}\left(\mathrm{E}_{1}\right), 750 \mathrm{ppm}\left(\mathrm{E}_{2}\right), 1000 \mathrm{ppm}\left(\mathrm{E}_{3}\right)$ and $1250 \mathrm{ppm}\left(\mathrm{E}_{4}\right)$. After each treatment, the fruits were air dried at ambient temperature for 30 minutes in an attempt to reduce possible chemical injury. The control fruits were dipped for five minutes in the distilled water without using the ethrel solution. Half fruits of all ethrel treatments are wrapped with paper $\left(\mathrm{P}_{1}\right)$ and remaining fruits are left without covering wrapper $\left(\mathrm{P}_{0}\right)$. The number of fruits treated under each treatment was ten, out of which four fruits were examined for their chemical composition in three replications at the interval of 2 days, 4 days, 6 days and 8 days after storage. The data collected for different observations were subjected to statistical analysis by adopting 'Analysis of variance' techniques as described by Steel and Torrie (1980) ${ }^{[23]}$.

\section{Results and Discussion}

The results obtained from the present investigation are summarized below:

\section{Fruit firmness $\left(\mathrm{kg} / \mathrm{cm}^{2}\right)$}

The data revealed that during the entire storage period ethrel exerted their significant effects on fruit firmness. Maximum firmness was noted in $\mathrm{E}_{0}$ (no ethrel) treatment at $2^{\text {rd }}, 4^{\text {th }}, 6^{\text {th }}$ and $8^{\text {th }}$ day of storage period $(6.27,5.83,5.38$ and $3.72 \mathrm{~kg} /$ $\mathrm{cm}^{2}$, respectively). While, minimum firmness at $2^{\text {rd }}, 4^{\text {th }}, 6^{\text {th }}$ and $8^{\text {th }}$ day of storage period $(5.38,4.56,3.73$ and 1.83 $\mathrm{kg} / \mathrm{cm}^{2}$, respectively) was recorded in ethrel $1250 \mathrm{mg} / \mathrm{l}\left(\mathrm{E}_{4}\right)$. The reduction in firmness with exogenous application of ethrel may be due to the increased activity of various enzymes involved in fruit softening as well as enhanced ripening (Nair and Singh, 2003) ${ }^{[24]}$. Similar results were obtained by Brinston et al. (1988) ${ }^{[1]}$, Dhillon and Mahajan (2011) ${ }^{[4]}$ in pear, Saeed et al. (2006) ${ }^{[16]}$ in banana, Hai et al. (2009) ${ }^{[7]}$ in "Tron" and "Hoi" mangoes, Nour and Goukh (2010) ${ }^{[13]}$ in white and pink-fleshed guava fruits and Siddiqui and Dhua (2009) ${ }^{[17]}$ in mango cv. Himsagar fruits.

In case of paper wrapping Fruits wrapped with paper recorded maximum firmness at $2^{\text {nd }}, 4^{\text {th }}, 6^{\text {th }}$ and $8^{\text {th }}$ day $(5.82,5.04,4.54$ and $2.81 \mathrm{~kg} / \mathrm{cm}^{2}$, respectively). While fruits without wrapping was shows minimum firmness at $2^{\text {nd }}, 4^{\text {th }}, 6^{\text {th }}$ and $8^{\text {th }}$ day of storage period $\left(5.73,4.91,4.42\right.$ and $2.71 \mathrm{~kg} / \mathrm{cm}^{2}$, respectively). Similar result was obtained by Jindal et al. $(2005)^{[9]}$ in sapota cv. Cricket Ball.

Table 1: Influence of post-harvest application of ethrel and paper wrapping on fruit firmness and physiological loss in weight of papaya (Carica papaya $\mathrm{L}$.) cv. Madhu Bindu

\begin{tabular}{|c|c|c|c|c|c|c|c|c|}
\hline \multirow[b]{2}{*}{ Treatments } & \multicolumn{4}{|c|}{ Fruit firmness $\left(\mathrm{kg} / \mathrm{cm}^{2}\right)$} & \multicolumn{4}{|c|}{ Physiological loss in weight (\%) } \\
\hline & 2 day & 4 day & 6 day & 8 day & 2 day & 4 day & 6 day & 8 day \\
\hline \multicolumn{9}{|c|}{ Ethrel (E) } \\
\hline $\mathrm{E}_{0}:$ No ethrel & 6.27 & 5.83 & 5.38 & 3.72 & 2.48 & 4.75 & 6.75 & 8.23 \\
\hline $\mathrm{E}_{1}$ : Ethrel @ $500 \mathrm{mg} / \mathrm{l}$ & 5.96 & 5.04 & 4.95 & 3.11 & 2.80 & 5.26 & 7.34 & 8.43 \\
\hline $\mathrm{E}_{2}:$ Ethrel @750mg/l & 5.71 & 4.81 & 4.23 & 2.93 & 3.07 & 5.42 & 7.43 & 8.79 \\
\hline $\mathrm{E}_{3}:$ Ethrel @ $1000 \mathrm{mg} / \mathrm{l}$ & 5.54 & 4.63 & 4.10 & 2.22 & 3.19 & 5.69 & 7.65 & 9.24 \\
\hline $\mathrm{E}_{4}$ : Ethrel @ $1250 \mathrm{mg} / \mathrm{l}$ & 5.38 & 4.56 & 3.73 & 1.83 & 3.66 & 6.42 & 8.24 & 10.64 \\
\hline S.Em. \pm & 0.05 & 0.05 & 0.06 & 0.05 & 0.06 & 0.15 & 0.22 & 0.26 \\
\hline C.D. at $5 \%$ & 0.14 & 0.16 & 0.17 & 0.16 & 0.17 & 0.43 & 0.66 & 0.77 \\
\hline \multicolumn{9}{|c|}{ Paper wrapping (P) } \\
\hline $\mathrm{P}_{0}:$ Without paper wrapping & 5.73 & 4.91 & 4.42 & 2.71 & 3.10 & 5.65 & 7.55 & 9.22 \\
\hline $\mathrm{P}_{1}$ : With paper wrapping & 5.82 & 5.04 & 4.54 & 2.81 & 2.98 & 5.37 & 7.42 & 8.91 \\
\hline S.Em. \pm & 0.03 & 0.03 & 0.04 & 0.03 & 0.04 & 0.09 & 0.14 & 0.17 \\
\hline C.D. at $5 \%$ & 0.09 & 0.10 & 0.11 & 0.10 & 0.11 & 0.27 & NS & NS \\
\hline
\end{tabular}

Table 2: Influence of post-harvest application of ethrel and paper wrapping on spoilage, days taken to ripening and shelf life of papaya (Carica papaya $\mathrm{L}$.) cv. Madhu Bindu

\begin{tabular}{|c|c|c|c|c|c|c|}
\hline \multirow{2}{*}{ Treatments } & \multicolumn{4}{|c|}{ Spoilage $(\%)$} & \multirow{2}{*}{ Days taken to ripening } & \multirow{2}{*}{ shelf life (Days) } \\
\hline & 2 day & 4 day & 6 day & 8 day & & \\
\hline \multicolumn{7}{|c|}{ Ethrel (E) } \\
\hline $\mathrm{E}_{0}:$ No ethrel & 0.00 & 13.61 & 34.91 & 69.99 & 5.33 & 7.50 \\
\hline $\mathrm{E}_{1}$ : Ethrel @ $500 \mathrm{mg} / \mathrm{l}$ & 0.00 & 20.26 & 44.09 & 76.94 & 4.88 & 6.13 \\
\hline $\mathrm{E}_{2}:$ Ethrel @750 mg/l & 0.00 & 27.39 & 50.93 & 83.64 & 4.12 & 6.00 \\
\hline $\mathrm{E}_{3}$ : Ethrel @1000 mg/l & 0.00 & 33.87 & 62.95 & 92.62 & 3.45 & 5.17 \\
\hline $\mathrm{E}_{4}$ : Ethrel @1250 mg/l & 0.00 & 43.34 & 75.94 & - & 2.60 & 4.17 \\
\hline S.Em. \pm & 0.00 & 1.31 & 2.19 & 3.09 & 0.07 & 0.20 \\
\hline C.D. at $5 \%$ & - & 3.85 & 6.47 & 9.26 & 0.20 & 0.58 \\
\hline \multicolumn{7}{|c|}{ Paper wrapping (P) } \\
\hline $\mathrm{P}_{0}:$ Without paper wrapping & 0.00 & 26.01 & 51.68 & 77.57 & 4.19 & 6.13 \\
\hline $\mathrm{P}_{1}:$ With paper wrapping & 0.00 & 29.37 & 55.85 & 84.03 & 3.96 & 5.73 \\
\hline
\end{tabular}




\begin{tabular}{|c|c|c|c|c|c|c|}
\hline S.Em. \pm & 0.00 & 0.83 & 1.39 & 2.18 & 0.04 & 0.12 \\
\hline C.D. at 5\% & - & 2.44 & 4.09 & NS & 0.13 & 0.37 \\
\hline
\end{tabular}

\section{Physiological loss in weight $(\%)$}

The variation in physiological loss in weight was observed significant due to different treatment. Minimum physiological loss in weight was noted in without ethrel $\left(\mathrm{E}_{0}\right)$ treatment during $2^{\text {nd }}, 4^{\text {th }}, 6^{\text {th }}$ and $8^{\text {th }}$ day storage $(2.48,4.75,6.75$ and $8.23 \%$, respectively) which was at par with $\mathrm{E}_{1}$ at $6^{\text {th }}$ and $8^{\text {th }}$ day of storage (7.34 and $8.43 \%$, respectively) and $E_{2}$ at $8^{\text {th }}$ day $(8.79 \%)$ of storage period. While, maximum physiological loss in weight was noted in ethrel $1250 \mathrm{mg} / \mathrm{l}\left(\mathrm{E}_{4}\right)$ treatment during $2^{\text {nd }}, 4^{\text {th }}, 6^{\text {th }}$ and $8^{\text {th }}$ day storage $(3.66,6.42,8.24$ and $10.64 \%$, respectively). This could be due to the fact that, higher ethylene concentration promoted the physiological processes such as respiration, transpiration which resulted into more physiological loss in weight due to moisture loss. Similar finding ware also recorded by Chauhan et al. (2012) ${ }^{[3]}$ in orange, Kulkarni et al. (2004) ${ }^{[10]}$ in mango fruits cv. Neelum and also Siddiqui and Dhua (2009) ${ }^{[17]}$ in mango fruits cv. Himsagar. Sachin Patil et al. (2009) ${ }^{[15]}$ in mango and Madhavi et al. (2005) ${ }^{[11]}$ in sapota.

In case of paper wrapping The minimum physiological loss in weight was noted in fruits wrapped with paper during $2^{\text {nd }}$ and $4^{\text {th }}$ day storage period (2.98 and $5.37 \%$, respectively) as compared to fruits without wrapping (3.10 and $5.65 \%$, respectively). Similar results were obtained by Somkuwar et

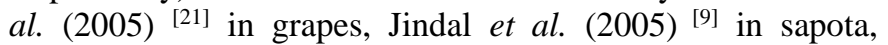
Chandra and Kumar (2012) ${ }^{[2]}$ in guava and Prasad et al. (2015) ${ }^{[14]}$ in banana.



Fig 1: Influence of post-harvest application of ethrel and paper wrapping on days taken to ripening and shelf life of papaya (Carica papaya $\mathrm{L}$.) cv. Madhu Bindu

\section{Spoilage (\%)}

The variation in spoiled fruit was also observed significant and lowest spoilage percentage at $4^{\text {th }}, 6^{\text {th }}$ and $8^{\text {th }}$ day of storage period $(13.61,34.91$ and $69.99 \%$, respectively) were recorded in without ethrel $\left(\mathrm{E}_{0}\right)$ which was at par with $\mathrm{E}_{1}$ (76.94\%) during $8^{\text {th }}$ day of storage period. While, highest spoilage percentage was noted in ethrel $1250 \mathrm{mg} / \mathrm{l}\left(\mathrm{E}_{4}\right)$ at $4^{\text {th }}$ and $6^{\text {th }}$ day of storage period $(43.34$ and $75.94 \%$, respectively). This might have occurred due to increased respiration rate, enzyme activities and dissolution of cell wall which ultimately lead to early softening and over-ripening of fruits. This trend of increased spoilage with increased ripeness is similar to that reported by Gupta and Jawandha (2010) ${ }^{[6]}$ for peaches. Similar results were reported in mango fruits by Singh et al. (2012c) ${ }^{[20]}$, Sapota fruits by Madhavi et al. (2005) ${ }^{[11]}$ and by Srivastava et al. (1971) ${ }^{[22]}$.
For paper wrapping maximum spoilage percentage was noted in fruits wrapped with paper during $4^{\text {th }}$ and $6^{\text {th }}$ day storage period (29.37 and $55.85 \%$, respectively) as compared to without wrapped fruit (26.01 and $51.68 \%$, respectively). It might be due to paper wrapping increase the ethylene content in the fruits which increase the ripening process or induce senescence. Similar results were obtained by Jindal et al. (2005) ${ }^{[9]}$ and Malik et al. (2015) ${ }^{[12]}$ in guava.

\section{Days taken to ripening}

Lowest day to start ripening (2.60 days) was recorded in treatment $\mathrm{E}_{4}$ follow by $\mathrm{E}_{3}$. While, highest day for attain ripening was required in $\mathrm{E}_{0}$ treatment. Ethylene probably brings about the climacteric, since in many fruits the rise in respiration is directly preceded by an elevation in the ethylene concentration. This respiratory climacteric can be induced by ethylene treatment without a simultaneous change in tissue permeability. It has also been reported that ethylene alters the proportion of individual transfer RNA species. This effect of ethylene may influence the transfer of $\mathrm{m}$ RNA and thus initiate ripening. Similar results were reported by Sing et al. (2012a) ${ }^{[18]}$ in papaya and Gama et al. (2015) ${ }^{[5]}$ in banana.

In case of paper wrapping, wrapped fruits require less day for ripening (3.96 day) as compare to unwrapped fruits (4.19 day). It might be due to paper wrapping increase the ethylene content in the fruits which increase the ripening process or early ripening. Similar results were obtained by Sing et al. $(2012 b)^{[19]}$ in papaya.

\section{Shelf life (Days)}

The maximum shelf life (7.5 days) was recorded when papaya fruits were treated with no ethrel $\left(\mathrm{E}_{0}\right)$ and the minimum $(4.17$ days) was recorded when papaya treated with ethrel 1250 $\mathrm{mg} / \mathrm{l}\left(\mathrm{E}_{4}\right)$. However it was explained by Holl (1977) ${ }^{[8]}$ that ethylene probably brings about the climacteric, since in many fruits the rise in respiration is directly preceded by an elevation in the ethylene concentration. This respiratory climacteric can be induced by ethylene treatment without a simultaneous change in tissue permeability. It has also been reported that ethylene alters the proportion of individual transfer RNA species. This effect of ethylene may influence the transfer of $\mathrm{m}$ RNA and thus initiate ripening also induce senescence. Similar results were reported by Sing et al. (2012 a) ${ }^{[18]}$ in papaya and Gama et al. (2015) ${ }^{[5]}$ in banana.

The unwrapped fruits shown significantly maximum $(6.13$ day) as compare to wrapped fruits (5.73 day). It might be due to paper wrapping increase the ethylene content in the fruits which increase the ripening process and also induce senescence. Similar results were obtained by Sing et al. (2012 b) ${ }^{[19]}$ in papaya.

\section{Reference}

1. Brinston K, Dey PM, John MA, Pridhan JB. Postharvest changes in Mangifera indica mesocarp walls and cytoplasmic polysaccharides! Phytochemistry. 1988; 27:719-723.

2. Chandra D, Kumar R. Qualitative effect of wrapping and cushioning materials on guava fruits during storage! Hort Flora Research Spectrum. 2012; 1(4):318-322.

3. Chauhan SK, Singh P, Jawa NK. Studies on the standardization of ripening techniques for oranges! 
Journal of Stored Products and Postharvest Research. 2012; 3(8):117-121.

4. Dhillon WS, Mahajan BVC. Ethylene and ethephon inducing fruit ripening in pear! Journal of Stored Products and Postharvest Research. 2011; 2(3):54-51.

5. Gama T, Jazi AT, Takawira M, Chiota WM. Influence of indigenous ripening methods on quality and shelf life of bananas! Midlands State University Journal of Science, Agriculture and Technology, 2015, 24-33.

6. Gupta N, Jawandha SK. Influence of maturity stage on fruit quality during storage of 'Earli Grande' peaches! Notulae Scientia Biologicae. 2010; 2(3):96-99.

7. Hai VT, Huong PT, Sruamsiri P, Hegele M, Wunsche JN. Effect of ethrel post-harvest applications on ripening of "Tron" and "Hoi" mangoes (Mangifera indica L.). Conference on international research food security, natural resource management and rural development. 2009.

8. Holl W. Fruit ripening! Plant Res. Dev., 1977; 5:117-126.

9. Jindal S, Beniwal LS, Sihag RP, Godara NR. Effect of different types of paper used as cushioning material, as individual wrapping and lining on shelf life of sapota! Hariyana Journal of Horticulture Science, 2005; 34(3, 4):266-267.

10. Kulkarni SG, Kudachikar VB, Vasantha MS, Prakash K, Aravinda Prasad B, Ramana KVR. Studies on effect of ethrel dip treatment on the ripening behaviour of mango (Mangifera indica L.) variety 'Neelum'! Journal of Food Science and Technology, 2004; 41(2):216-220.

11. Madhavi M, Srihari D, Dilip Babu J. Effect ofpost harvestethrel treatment on ripening and of sapota cv. Pala fruits.! Indian Journal of Horticulture. 2005; 62(2):187189.

12. Malik AA, Bhat A, Ahmed N, Kaul R. Effect of postharvest application of plant extracts on physical parameters and shelf life of guava! Asian Agri-History. 2015; 19(3):185-193.

13. Nour IBM, Goukh ABAA. Effect of ethrel in aqueous solution and ethylene released from ethrel on guava fruit ripening! Agri. and Bio. J Nort Amer. 2010; 1(3):232237.

14. Prasad R, Ram RB, Kumar V, Rajvanshi SK. Study on effect of different packaging materials on shelf life of banana (Musa paradisiaca L.) cv. Harichal Under Different Conditions! Int. J Pure App. Biosci, 2015; 3(4):132-141.

15. Sachin Patil, Shinde Ganesh, Varu DK, Viradia RR. Effect of post-harvest treatments on physiological characters of mango cv. kesar during storage! The Asian Journal of Horticulture. 2009; 4(1):141-144.

16. saeed Ahmad S, Ahmad chatha Z, Nasir M, Aziz A, Mohson M. Effect of relative humidity on the ripening behaviour and quality of ethylene treated banana fruit! Journal of Agriculture \& Social Science. 2006; 2(1):5457.

17. Siddiqui MW, Dhua RS. Standardization of ethrel treatment for inducing ripening of mango var. 'Himsagar'! In Proceedings of International Conference on Horticulture (ICH-2009), Bangalore, 2009, 9-12.

18. Singh P, Kumar S, Maji S. Effect of ethrel on postharvest changes in papaya (Carica papaya L.) fruits! Hort Flora Research Spectrum, 2012a; 1(3):225230.

19. Singh P, Kumar S, Maji S. Effect of different wrapping materials on post-harvest changes in papaya (Carica papaya L.)! Environment and Ecology. 2012b; 30(3A): 773-777.

20. Singh P, Singh MK, Kumar V, Kumar M, Malik S. Effect of physico-chemical treatments on ripening behavior and post-harvest quality of Amrapali mango (Mangifera indica L.) during storage! Journal of environmental biology. 2012c; 33:227-232.

21. Somkuwar RG, Ramteke SD, Shikhamany SD. Effect of polyliners and tissue papers in packages on storage-life of Thompson Seedless! Indian Journal of Horticulture. 2005; 62(1):60-61.

22. Srivastava DC, Verma AN, Mishra HR, Sharma RK. Post-harvest changes during low temperature storage of South Indian mango varieties Neelum and Rumani! Mysore Journal of Agricultural Science. 1971; 5(1):96100.

23. Steel RGD, Torrie JH. Principles and procedures of statistics: a biometrical approach New York, USA: McGraw-Hill. 1980, 633.

24. Suresh Nair, Zora Singh. Pre-storage ethrel dip reduces chilling injury, enhances respiration rate, ethylene production and improves fruit quality of 'Kensington' mango! Journal of Food, Agriculture \& Environment. 2003; 1(2):93-97.

25. Watada LE, Herner RC, Kader AA, Romani RI, Staby GL. Terminology for the description of developmental stages of horticultural crops! J Amer. Soc. Hort. Sci. 1984; 19:20. 